(antacid) tends to stick in the mind. Glaxo is now showing signs of a mild addiction to names beginning with Z-Zinacef, Zinnat, Zofran. Tixylix (Intercare) is an odd name by any standards and is difficult to spell. It does, however, have a certain charm and sounds attractive. Prefil (Norgine), the appetite suppressant, is a minor classic of its kind: two syllables; simple; and the name captures the action of the product beautifully.

The prize for making the best use of seven letters must go to ICI for its succession of $\beta$ blockers: Alderin, Eraldin, and Inderal. There is still a good bit of milage left in this combination-Derlain, Darnile, Rednail, and Ireland would do for another four $\beta$ blockers.

Most of the following are not available in English speaking countries and we believe that they are unlikely to make it internationally. Would you buyor prescribe-Arsobal, Bumal, Kriplex, Nokhel, Rogorin, Snootie, or Widocillin?

1 Heller J. Catch 22. London: Cape. 1962.

2 Tolstoy L. Anna Karenina. London: Penguin, 1954.

Eliot TS. The naming of cats. In: Old Possum's book of practical cats. London: Faber and Faber, 1939

Swiss Pharmaceutical Society. Index nominum. Stuttgart: Medpharm Scientific Publications, 1990

5 Hoffman JP. More on "Losec or Lasix." N Engl f Med 1990;323:1428. Faber J, Azzugnuni M, Di Romana S, Vanhaeverbeek M. Fatal confusion between "Losec" and "Lasix." Lancet 1991;337:1286-7.

7 Kurth MC, Langston JW, Tetrud JW. "Stelazine" versus "Selegiline"-a hazard in prescription writing. $N$ Engl 3 Med 1990;323:1776.

8 Blain J. Faux semblants. Revue Prescrire 1990 October.

9 British Medical Association and Royal Pharmaceutical Society of Great Britain. British national formulary No 21. London: BMA, Pharmaceutical Press, 1991.

\title{
How heavy the patient?
}

\section{Kirsten McKay, S Fozdar-Faroudi, Clive E Bowman}

The measurement and monitoring of a patient's weight is a particularly useful index of progress in clinically diverse conditions such as pregnancy, heart failure, and ascites. We report a recent incident in our hospital in which uncertainty about a patient's weight occurred owing to failure of equipment.

\section{Case report}

A patient with decompensated alcoholic liver disease

Western General Hospital, Weston Super Mare, Avon BS23 4TQ

Kirsten McKay, MB, house physician

S Fozdar-Faroudi, PHD, senior house officer Clive E Bowman, MRCP, consultant physician

Correspondence to: Dr Bowman.

BMF 1991;303:1608
Patient's weight according to type of equipment at various location within hospital

\begin{tabular}{|c|c|c|}
\hline Location & Type of equipment & Weight (kg) \\
\hline \multicolumn{3}{|l|}{ Medical ward: } \\
\hline & Sitting, sliding weight balance & $62 \cdot 9$ \\
\hline B & Sitting, sliding weight balance & $63 \cdot 6$ \\
\hline & Hoist with electronic weight & \\
\hline C & $\begin{array}{l}\text { readout } \\
\text { Sitting electronic device }\end{array}$ & $\begin{array}{l}63 \cdot 4 \\
62 \cdot 1\end{array}$ \\
\hline $\mathrm{D}$ & Sitting scale & Non-functioning \\
\hline \multicolumn{3}{|l|}{ Surgical ward: } \\
\hline $\mathrm{A}$ & $\begin{array}{l}\text { Standing weight balance } \\
\text { "Bathroom" scales }\end{array}$ & $\begin{array}{l}61 \cdot 0 \\
62 \cdot 5\end{array}$ \\
\hline \multirow[t]{2}{*}{ B } & Sitting weight balance & $62 \cdot 5$ \\
\hline & "Bathroom" scales & $61 \cdot 0$ \\
\hline $\mathrm{C}$ & Sitting weight balance & $62 \cdot 4$ \\
\hline Antenatal ward & "Bathroom" scales & $62 \cdot 0$ \\
\hline \multicolumn{3}{|c|}{ Intensive care or cardiac } \\
\hline care & Sitting weight balance & $62 \cdot 5$ \\
\hline $\begin{array}{l}\text { Accident and emergency } \\
\text { department }\end{array}$ & "Bathroom" scales & $64 \cdot 0$ \\
\hline Outpatient department & Standing weight balance & $62 \cdot 9$ \\
\hline Considered weight & & $62 \cdot 5$ \\
\hline
\end{tabular}

\section{Comment}

This patient avoided potentially dangerous therapeutic changes by drawing our attention to the variation in equipment used for his weighing. We noted that there were 10 varieties of weighing device currently in use in the hospital and that the greatest consistency of results seemed to be obtained with older, sliding weight devices. Simple equipment may not be high tech, but, as has been shown for sphygmomanometers, ${ }^{\prime}$ equipment whose working can be understood is far less likely to become inaccurate.

Clearly, weighing devices must be regularly checked and calibrated. Patients having important sequential measurements should be weighed consistently on the same equipment and the scales used identified on their charts. Finally, the purchase of weighing devices should be subject to proper technical scrutinydomestic bathroom scales are simply not adequate for clinical practice.

We thank Gary James, medical artist at Bristol Royal Infirmary, for the illustration, and our patient.

1 Bowman CE. Blood pressure errors with aneroid sphygmomanometers. Lancet
$1981 ; \mathrm{i}: 1005$.

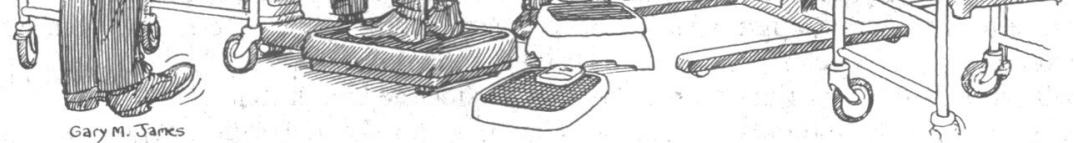

